\title{
Membentuk Karakter melalui Kegiatan Ekstrakurikuler Pramuka pada Anak Usia 6-8 Tahun
}

\author{
Nurdin'1, Jahada ${ }^{2}$, Laode Anhusadar ${ }^{\square}$ \\ Pendidikan Islam Anak Usia Dini, Institut Agama Islam Negeri Kendari, Indonesia(1) \\ Pendidikan Jasmani, Kesehatan Dan Rekreas, Universitas Haluoleo, Indonesia( ${ }^{(2)}$ \\ DOI: 10.31004/obsesi.v6i2.1603
}

\begin{abstract}
Abstrak
Penelitian ini bertujuan untuk menganalisis strategi kegiatan ekstrakurikuler pramuka dalam membentuk karakter peserta didik. Penelitian ini merupakan penelitian kualitatif, data dikumpulkan melalui observasi, wawancara dan dokumentasi. Data kemudian dianalisis dengan tahapan reduksi data, penyajian data, verifikasi dan kesimpulan. Penelitian ini dilakukan selama 6 bulan mulai bulan April-September 2019 dengan informan guru dan peserta didik. Lokasi penelitian ini adalah SDN 1 Talaga dan SDN 2 Talaga. Hasil penelitian menunjukan bahwa perencanaan kegiatan ekstrakurikuler pramuka dalam membentuk karakter peserta didik memuat pengetahuan dan keterampilan kepramukaan dengan perencanaan jangka panjang dan jangka pendek. Kemudian pelaksanaan kegiatan ekstrakurikuler pramuka dalam membentuk karakter peserta didik terbagi atas pengetahuan dan ketereampilan atau tehnik kepramukaan. Selanjutnya evaluasi kegiatan ekstrakurikuler pramuka dalam membentuk karakter peserta didik terbagi atas evaluasi bagi peserta didik dan evaluasi bagi pembinanya dalam hal ini guru-guru.
\end{abstract}

Kata Kunci: karakter; ekstrakurikuler pramuka; anak usia 6-8 tahun.

\begin{abstract}
This study aims to analyze the scout extracurricular activities in shaping the character of students. This research is qualitative, data collected through observation, interviews and documentation. The data were then analyzed with the stages of data reduction, data presentation, levers and conclusions. This research was conducted for 6 months starting from April-September 2019 with teacher and student informants. The results showed that: Planning for scout extracurricular activities in shaping the character of students contains scouting knowledge and skills with long-term and short-term planning. Then the implementation of scout extracurricular activities in shaping the character of students is divided into knowledge and skills or scouting techniques. Furthermore, scout extracurricular activities in shaping the character of students are divided into evaluations of evaluation and evaluation of their part in this case the teachers.
\end{abstract}

Keywords: character; scout extracurricular; 6-8 years old.

Copyright (c) 2021 Nurdin, et al.

$\triangle$ Corresponding author:

Email Address : sadar.wanchines@gmail.com (Kendari, Indonesia)

Received 2 March 2021, Accepted 26 July 2021, Published 272021 


\section{PENDAHULUAN}

Pendidikan karakter secara esensial tercermin dalam fungsi dan tujuan pendidikan sebagaimana dicantumkan dalam Undang-undang No. 20 Tahun 2003 tentang Sistem Pendidikan Nasional Pasal 3 bahwa pendidikan nasional berfungsi mengembangkan kemampuan dan membentuk watak serta peradaban bangsa yang bermartabat dalam rangka mencerdaskan kehidupan bangsa, bertujuan untuk berkembangnya potensi peserta didik agar menjadi Manusia yang beriman dan bertakwa kepada Tuhan Yang Maha Esa, berakhlak mulia, sehat, berilmu, cakap, kreatif, mandiri, dan menjadi warga negara yang demokratis serta bertanggung jawab (Wahyuni \& Erdiyanti, 2020).

Sunardi menyatakan bahwa gerakan pramuka adalah salah satu pendidikan non formal yang memiliki tujuan untuk menanamkan karakter dan membentuk kepribadian yang baik dalam diri anak dengan cara keteladanan, arahan, bimbingan (Surono, 2018). Kemudian dalam Permendikbud no. 63 tahun 2014 ini akan memberikan penguatan pada pendidikan karakter disekolah, karena yang sebelumnya pramuka hanya sebatas Ekstrakurikuler biasa dan bisa ditiadakan di sekolah dan tidak masuk dalam mata pelajaran dengan keluarnya Permendikbud diatas maka Ekstrakurikuler pramuka menjadi wajib disetiap sekolah dan bagi sekolah yang telah menerapkan kurikulum 2013 pramuka telah dimasukan dalam mata pelajaran sebanyak 2 Jam perminggunya(Hidayat et al., 2019).

Kegiatan ekstrakurikuler pramuka juga merupakan serangkaian program kegiatan belajar mengajar untuk meningkatkan cakrawala pandang peserta didik menumbuhkan bakat dan minat serta semangat pengabdian kepada masyarakat. Kegiatan pramuka itu sendiri memiliki kode penghormatan dan pengabdian yakni suatu norma atau nilai-nilai luhur dalam kehidupan. Jika peserta didik yang telah mengikuti pendidikan pramuka dan mereka bisa merealisassikan di dalam kehidupan sehari-hari sesuai dengan kode kehormatan kepramukaan, maka peserta didiknya pun akan memiliki karakter yang baik dalam diri mereka. Hasil penelitian Nailil menyimpulkan bahwa pertama, Materi dalam kegiatan kepramukaan yang mengandung nilai-nilai karakter yaitu memiliki kesamaan pada tujuan, prinsip, metodologi yang mengarah pada penanaman dan pengembagan nilai-nilai Pendidikan yang tercermin pada Undang-undang Gerakan Pramuka, serta Anggaran Dasar dan Anggaran Rumah Tangga Gerakan Pramuka. Kedua, upaya Guru dalam penanaman nilai karakter dengan menggunakan sistem among, mengelola satuan pramuka, memahami peserta didik sesuai dengan kebutuhannya, serta menciptakan kegiatan yang menarik, menyenagkan dan mengandung nilai pendidikan (Santoso \& Hikmah, 2015).

Gerakan pramuka sebagai organisasi kepanduan yang berkecimpung dalam dunia pendidikan yang bersifat non formal berusaha membantu Guru dan masyarakat dalam membangun masyarakat dan bangsa. Hal ini dilihat dari prinsip dasar metodik pendidikan pramuka, yaitu yang tertera dalam Dasadarma Pramuka: (1)Takwa kepada Tuhan Yang Maha Esa, (2) Cinta alam dan kasih sayang sesama manusia, (3) Patriot yang sopan dan kesatria, (4) Patuh dan suka bermusyawarah, (5) Rela menolong dan tabah, (6)Rajin, terampil, dan gembira, (7)Hemat cermat, dan bersahaja, (8) Disiplin, berani, dan setia, (9) Bertanggungjawab dan dapat dipercaya, (10)Suci dalam pikiran, perkataan, dan perbuatan (Agus Widodo, 2003). Hal ini sesuai dengan hasil penelitian yang dilakukan oleh Marsuki yang menyimpulkan bahwa peran pembina pramuka sebagai mitra atau pembimbing, memberikan dukungan dan memfasilitasi peserta didik dengan kegiatan yang modern, menarik, dan menantang. Metodenya antara lain: pengamalan kode kehormatan pramuka pada setiap kegiatan; kegiatan belajar sambil melakukan, berkelompok, bekerja sama, dan berkompetisi kegiatan di alam terbuka seperti perkemahan; penghargaan berupa tanda kecakapan bantara dan laksana serta satuan terpisah ambalan putra dan putri. Hambatan yang muncul antara lain adalah kurangnya perhatian guru terhadap masalah pramuka danbanyaknya peserta didik yang tidak suka mengikuti kegiatan kepramukaan. Upaya untuk mengatasinya dengan mengajak para guru ikhlas melakukannya dan menciptakan kegiatan yang menarik dan menantang peserta didik (Marzuki \& Hapsari, 2015). 
Dengan menciptakan kegiatan yang menarik ini dapat dilakukan melalui kegiatan ekstrakurikuler seperti kepramukaan. Dalam kegiatan kepramukaan ini diharapkan dapat membentuk karakter siswa yang mengikuti kegiatan kepramukaan. Menurut Daniel Golemen dalam bukunya Kecerdasan Ganda menyebutkan bahwa kecerdasan emosional dan sosial dalam kehidupan dibutuhkan $80 \%$, sedangkan kecerdasan intektual hanya sebesar $20 \%$ (Muhammad, 2015). Untuk itu pendidikan karakter akan mudah diberikan melalui jalur pendidikan, salah satunya adalah pendidikan nonformal pramuka. Jadi kecerdasan emosional dan sosial lebih membawa dampak pada perjalanan hidup bahkan karier anak di kemudian hari. Berbagai media bisa digunakan untuk pendidikan karakter, salah satunya melalui kepramukaan.

Banyaknya kasus krisis karakter ini membuat pendidik harus memaksimalkan pendidikan karakter yang ada. Kemendikbud tahun 2010 menyebutkan bahwa terdapat 18 karakter yang harus dimiliki oleh peserta didik yaitu karakter religius, jujur, toleransi, disiplin, kerja keras, kreatif, mandiri, demokratis, rasa ingin tahu, semangat kebangsaan, cinta tanah air, menghargai prestasi, bersahabat atau komunikatif, cinta damai, gemar membaca, peduli lingkungan, peduli sosial, dan tanggung jawab (Ikawati Rahayuningtyas \& Mustadi, 2013). Peningkatan karakter ini dapat dilakukan melalui kegiatan Ekstrakurikuler pramuka. Kondisi ini merupakan momentum yang tepat untuk melaksanakannya sebagai "perwujudan dari gagasan pendidikan karakter agar tujuan dari pendidikan karakter dapat tercapai, dan mempunyai pengaruh terhadap belajar peserta didik" (Wiyani, 2012).

Sebagai pendidikan dasar, karakter religius sangat penting karena mencakup hubungan kepada Tuhannya dan melatih jiwa untuk memiliki sifat jujur dan bersih. Adapun karakter nasional sebagai pondasi kebangsaan dan cinta akan tanah air. Sedangkan karakter gotong royong untuk melatih jiwa kepedulian dan kebersamaan peserta didik dalam hidup bersosial. Kemudian karakter disiplin juga sangat penting agar tidak buta akan sebuah tanggung jawab dan lebih produktif. Dalam rangka mewujudkan penerapan karakter terhadap anak maka setiap kegiatan dan pelaksanaan kegiatan diperlukan manajemen berupa perencanaan, pelaksanaan dan evaluasi untuk mengelolanya agar kegiatan tersebut dapat berjalan dengan baik dan tujuan kegiatan dapat tercapai. Begitupun dengan kegiatan pramuka yang akan dilakukan, dalam upaya membentuk karakter anak tentunya dalam setiap pelaksanaan kegiatan pramuka harus ada direncanakan secara berkala agar tujuan kegiatan dalam menumbuhkan karakter anak dapat tercapai dengan baik. Sehingga terlihat efek atau dampak dalam membentuk karakter peserta didik tersebut.

\section{METODOLOGI}

Penelitian yang digunakan adalah metode penelitian kualitataif dengan pendekatan deskriptif. Penelitian ini dilaksanakan pada SDN 1 dan SDN 2 Talaga Raya. Adapun alasan penulis memilih tempat penelitian ini ialah karena kegiatan ekstrakulikuler di sekolah Dasar ini terbilang aktif. Selain itu pemilihan tempat penelitian ini ialah karena daerah ini merupakan daerah 3T yang di Provinsi Sulawesi Tenggara. Adapun waktu pelaksanaan penelitian ini akan dilaksanakan pada bulan April-September 2019. Adapun sumber data yang digunakan dalam penelitian ini, yaitu data primer dan data sekunder. Data primer dalam penelitian ini adalah data yang diambil peneliti melalui observasi dan wawancara para informan yaitu para guru dan peserta didik yang berada pada kelas 1 dan 2 Sekolah Dasar. Adapun pengumpulan data yang dilakukan dengan observasi, dokumentasi dan wawancara. Menurut Sugiono analisis data kualitatif dilakukan dengan koleksi data, reduksi data, penyajian data dan kesimpulan (Shaleh \& Anhusadar, 2021). 




Gambar 1. Bagan Analisis Data Kualitatif.

\section{HASIL DAN PEMBAHASAN}

Perencanaan merupakan salah satu fungsi dari manajemen yang paling penting dan perencanaan kegiatan ekstrakurikuler pramuka adalah tahap awal dalam kegiatan ekstrakurikuler pramuka. Terdapat beberapa perencaan menurut Amida bahwa: ada beberapa yang kami rencanakan dalam kegiatan ekstrakurikuler pramuka, diantaranya adalah menetapkan kebijakan kegiatan kepramukaan, merumuskan tujuan kegiatan kepramukaan, menentukan alat lunak pendidikan karakter dan keterampilan pendidikan karakter dalam kegiatan kepramukaan, membuat program semesteran kegiatan kepramukaan dan membuat program mingguan kegiatan kepramukaan (wawancara 15 Juli 2019). Selanjutnya perihal perencanaan kegiatan Ekstrakurikuler Pramuka ini informan Asria Ado lebih merincikan perencanaan kegiatan ekstrakurikuler pramuka dalam membentuk karakter pserta didik, sebagaimana ungkapannya bahwa: perencanaan kegiatan ekstrakurikuler pramuka SDN I Talaga Raya, yaitu perencanaan jangka pendek diantaranya latihan rutin, pendalaman tata cara upacara, dan latihan kegiatan baris berbaris. Kemudian perencanaan jangka panjang diantaranya perkemahan sabtu minggu (PERSAMI) (Wawancara, 15 Juli 2019). Kemudian terkait perencanaan kegiatan ekstrakurikuler pramuka dalam membentuk karakter peserta didik di SDN 2 Talaga Raya, tidak jauh beda dengan data yang Guru SDN 1 Talaga Raya bahwa: Perencanaan kegiatan ekstrakurikuler pramuka mencakup pengetahuan dan keterampilan peserta didik, diantaranya adalah keterampilan tali temali, keterampilan pertolongan pertama gawat darurat, ketreampilan Morse dan semaphore, keterampilan membaca sandi pramuka, penjelajahan dengan tanda jejak, kegiatan saka bahari, keterampilan baris berbaris dan keterampilan menentukan arah (Wawancara Hasanudin, 15 Juli 2019).

Berdasarkan hasil wawancara di atas, maka diperoleh data bahwa secara garis besar perencanaan kegiatan ekstrakurikuler pramuka dalam membentuk karakter peserta didik di SDN I dan SDN 2 Talaga Raya terbagi menjadi 2 (dua) perencanaan yang memuat pengetahuan dan keterampilan kepramukaan. Perencanaan tersebut ialah perencanaan jangka panjang dan jangka pendek. Adapun untuk perencanaan jangka panjang ialah perkemahan sabtu minggu (PERSAMI), pelantikan kenaikan pangkat dan kegiatan lomba. Sedangkan perencanaan jangka pendek ialah pendalaman tata cara upacara, latihan kegiatan baris berbaris dan latihan rutin pendalaman materi dan keterampilan berupa keterampilan tali temali, keterampilan pertolongan pertama gawat darurat, ketereampilan Morse dan semaphore, keterampilan membaca sandi pramuka, penjelajahan dengan tanda jejak, kegiatan saka bahari dan keterampilan menentukan arah.

Pelaksanaan kegiatan ekstrakurikuler pramuka merupakan tahap selanjutnya yang dilakukan setelah perencanaan. Segala sesuatu yang telah direncanakan akan di lakukan pada tahapan pelaksanaan ini. Adapun pelaksanaan kegiatan ekstrakurikuler pramuka dalam membentuk karakter peserta didik di SDN 2 Talaga Raya menurut informan Hasanudin kegiatan terbagi atas dua pelaksanaan. Sebagaimana ungkapannya bahwa: untuk pelaksanaanya pun terbagi atas 2 bagian, pertama yaitu pengetahuan berupa pengetahuan sejarah kepramukaan dan pengetahuan umum kemudian yang kedua adalah tehnik 
kepramukaan diantaranya smaphore, morse, tali emali, mapping, baris berbaris dan sandisandi (wawancara, 15 Juli 2019). Terkait pelaksanaan kegiatan ekstrakurikuler pramuka dalam membentuk karakter peserta didik di SDN I Talaga Raya ini sedikit berbeda dengan data yang diperoleh dari Ibu Haslia beliau mengungkapkan bahwa: setelah membuat perencanaan, selanjutnya membuat Rencana Aksi Lapangan. Rencana Aksi Lapangan merupakan sebuah perencanaan yang dibuat oleh guru pembina pramuka disetiap latihan. Didalam Rencana Aksi Lapangan harus memuat identitas sekolah, tingkatan, semester, than pelajaran, alokasi waktu, tujuan, indikator, materi kegiatan, skenario kegiatan, media, dan penilaian kegiatan (Wawancara, 15 Juli 2019).

Sedangkan data dari informan Ibu Hartati selaku salah satu Guru SDN I Talaga Rayameng kategorikan pelaksanaan kegiatan ekstrakurikuler pramuka dalam membentuk karakter peserta didik di SDN I Talaga Raya ini menjadi 4 bagian yaitu perencanaan ekstrakurikuler pramuka meliputi kegiatan menentukan tujuan ekstrakurikuler, sasaran ekstrakurikuler, jadwal kegiatan dan pembina ekstrakurikuler pramuka. Pengorganisasian ekstrakurikuler pramuka meliputi, pembagian tugas, kerjasama yang di bangun dengan pihak eksternal dan pengelompokkan peserta didik. Penggerakkan ekstrakurikuler pramuka meliputi, pelaksanaan kegiatan ekstrakurikuler pramuka, partisipasi peserta didik dan sistem penilaian peserta didik. Pengawasan ekstrakurikuler pramuka dilaksanakan dengan pelaporan secara lisan ataupun tertulis (Wawancara, 15 Juli 2019).

Berdasarkan hasil wawancara di atas, maka diperoleh data bahwa pelaksanaan kegiatan ekstrakurikuler pramuka dalam membentuk karakter peserta didik di SDN I dan SDN 2 Talaga Rayaterbagi atas 2 (dua) pelaksanaan. Pertama adalah pengetahuan berupa pengetahuan sejarah kepramukaan dan pengetahuan umum, kemudian yang kedua adalah tehnik kepramukaan diantaranya keterampilan tali temali, keterampilan pertolongan pertama gawat darurat, ketereampilan Morse dan semaphore, keterampilan membaca sandi pramuka, penjelajahan dengan tanda jejak, kegiatan saka bahari dan keterampilan menentukan arah.

Dalam setiap kegiatan ekstrakurikuler pramuka mempunyai dampak tersendiri, baik itu dampak positif maupun dampak negatif. Berdasarkan dari beberapa data yang diperoleh, kegiatan ekstrakurikuler pramuka berdampak positif dalam membentuk karakter peserta didik di SDN I dan SDN 2 Talaga Raya dengan usaha-usaha pembiasaan baik dan sanksi yang bersifat mendidik. Sebagaimana yang diungkapakan informan Amida bahwa: upaya pembentukan karakter peserta didik melalui kegiatan pramuka dilakukan dengan pembiasaan, contoh teladan, pemberian tugas, memberikan ceramah atau nasihat-nasihat,dan pemberian sanksi jika peserta didik (anggota Pramuka) melakukan kesalahan. Kegiatan pembiasaan dilakukan dengan mengadakan latihan rutin setiap hari kami (Wawancara, 15 Juli 2019). Selanjutnya ditambahkan oleh informan Bapak Hasanudin mengungkapkan bahwa: dampak dari kegiatan ekstrakurikuler pramuka ialah dapat membentuk generasi penerus bangsa yang mandiri. Banyak hal yang menjadikan pengembangan kedisiplinan pada anak seperti mereka mampu mengatur dirinya dan bertanggung jawab terhadap dirinya sehingga menjadi pribadi yang lebih baik di sekolah maupun di rumah, mereka mampu mengontrol tingkah lakunya sehingga tugas-tugas di sekolah maupun di rumah dapat berjalan dengan optimal. Melalui aturan-aturan yang harus ditaati, pemberian penghargaan bagi mereka yang mampu menjadi contoh bagi peserta didik lainnya, memberikan hukuman mendidik sebagai alat pendorong kedisiplinan, serta konsisten dalam mengikuti kegiatan belajar di sekolah dan mengikuti kegiatan pramuka (Wawancara. 15 Juli 2019).

Kemudian dipertegas oleh informan Ibu Haslia bahwa: Peserta didik menekuni denagan sungguh-sungguh kegiatan ekstrakurikuler yang dipilih sesuai dengan minat, bakat dan potensi yang dimiliki. Dan dengan tidak sadar berdampak positif bagi mereka. Salah satunya ialah dapat meningkatkan sikap disiplin peserta didik baik disiplin waktu, disiplin dalam berpakaian, dan disiplin mematuhi peraturan. Selain itu adanya sikap saling menghormati dan menghargai baik sesama teman maupun kepada pembina dan guru-guru (Wawancara, 15 Juli 2019). Berdasarkan hasil pengamatan langsung peneliti selama berada di 
lokasi penelitian menemukan bahwa peserta didik yang aktif mengikuti kegiatan ekstrakurikuler pramuka memiliki sikap disiplin yang berbeda dengan peserta didik yang yang tidak aktif mengikuti ekstrakurikuler pramuka, hal ini bisa dilihat dari kehadiran peserta didik dalam mengikuti proses pembelajaran di sekolah. Dari cara berpakaian peserta didik yang mengikuti kegiatan ekstrakurikuler yang aktif lebih rapi dan sopan santun dalam bertutur kata.

Berdasarkan hasil wawancara di atas, maka diperoleh data bahwa dampak kegiatan ekstrakurikuler pramuka dalam membentuk karakter peserta didik di SDN I dan SDN 2 Talaga Raya yaitu berdampak positif. Dampak positif yang didapatkan peserta didik pada kegiatan ekstrakurikuler pramuka ialah dapat meningkatkan sikap disiplin peserta didik baik disiplin waktu, disiplin dalam berpakaian, dan disiplin mematuhi peraturan. Selain itu dapat meningkatkan sikap saling menghormati dan menghargai baik sesama teman maupun guruguru.

Pembinaan kegiatan ekstrakurikuler bidang pramuka SDN I dan SDN 2 Talaga Raya harus memiliki manajemen yang baik agar kegiatan dapat terlaksana secara efektif dan efesien. Karena manajemen adalah sebagai pengelola sumber-sumber guna mencapai suatu tujuan yang telah ditetapkan. Artinya, manajemen adalah sebagai suatu proses yang diterapkan oleh individu atau kelompok dalam upaya-upaya koordinasi untuk mencapai suatu tujuan (Pimay, 2013, h. 1). Manajemen ini memegang peranan yang sangat penting dalam dunia organisasi sehingga dengan adanya manajemen yang baik semua yang ada berjalan dengan lancar.

Dalam proses pengorganisasian ini akan berhubungan erat dengan perencanaan, pengorganisasian, pelaksanaan, dan pengawasan. Sedangkan manajemen adalah salah satu displin ilmu yang implikasinya menerapkan proses- proses tersebut. Maka dalam penerapan pelaksanaan kurikulum, seorang yang mengelola lembaga pendidikan harus menguasai ilmu manajemen, baik untuk mengurus pendidikan ataupun kurikulumnya (Nasbi, 2017). Berdasarkan data yang diperoleh bahwa secara garis besar perencanaan kegiatan ekstrakurikuler pramuka dalam membentuk karakter peserta didik di SDN I dan SDN 2 Talaga Rayaterbagi menjadi 2 perencanaan yang memuat pengetahuan dan keterampilan kepramukaan. Perencanaan tersebut ialah perencanaan jangka panjang dan jangka pendek. Perencanaan tersebut diperuntukan untuk dikerjakan dimasa yang akan datang dalam rangka mencapai tujuan. Menurut Aderson sebagaimana yang dikutip oleh Rambe, mengatakan bahwa perencanaan adalah proses mempersiapkan seperangkat keputusan bagi perbuatan dimasa datang (Rambe, 2016). Adapun untuk perencanaan jangka panjang ialah perkemahan sabtu minggu (PERSAMI), pelantikan kenaikan pangkat dan kegiatan lomba. Sedangkan perencanaan jangka pendek ialah pendalaman tata cara upacara, latihan kegiatan baris berbaris, dan latihan rutin pendalaman materi dan keterampilan berupa keterampilan tali temali, keterampilan pertolongan pertama gawat darurat, ketereampilan Morse dan semaphore, keterampilan membaca sandi pramuka, penjelajahan dengan tanda jejak, kegiatan pengembaraan dan keterampilan menentukan arah.

Setelah dilakukan perencanaan, selanjutnya masuk pada tahap pelaksanaan sebagai proses dalam bentuk rangkaian kegiatan. Bintoro Tjokroadmudjoyo dalam mengungkapkan pelaksanaan ialah sebagai proses dalam bentuk rangkaian kegiatan, yaitu berawal dari kebijakan guna mencapai suatu tujuan maka kebijakan itu diturunkan dalam suatu program dan proyek. Selain dalam bentuk rangkaian kegiatan, pelaksanaan juga menjadi rangkaian tindak lanjut dari program sekolah yang sudah diputuskan (Gartina et al., 2019). Menurut Abdullah pelaksanaan adalah suatu proses rangkaian kegiatan tindak lanjut program sekolah atau kebijaksanaan yang terdiri atas pengambilan keputusan, langkah yang startegis maupun operasional atau kebijakan menjadi kenyataan guna mencapai sasaran dari program yang ditetapkan semula (Usman, 2016). Pelaksanaan kegiatan ekstrakurikuler pramuka dalam membentuk karakter peserta didik di SDN I dan SDN 2 Talaga Rayaterbagi atas 2 (dua) pelaksanaan. Pertama adalah pengetahuan berupa pengetahuan sejarah kepramukaan dan 
pengetahuan umum, kemudian yang kedua adalah tehnik kepramukaan diantaranya keterampilan tali temali, keterampilan pertolongan pertama gawat darurat, ketereampilan Morse dan semaphore, keterampilan membaca sandi pramuka, penjelajahan dengan tanda jejak, kegiatan pengembaraan dan keterampilan menentukan arah.

Kedisiplinan peserta didik memang harus diperhatikan karena kedisiplinan merupakan kunci awal pembentukan karakter yang lainnya bagi peserta didik. Kedisiplinan yang diajarkan dalam kegiatan pramuka memiliki peranan penting dalam membentuk peserta didik. Sofchah Sulistyowati mengemukakan bahwa indikator seorang pelajar dapat belajar dengan baik ia harus bersikap disiplin, terutama disiplin dalam hal menepati jadwal belajar, disiplin dalam mengatasi semua godaan yang akan menunda-nunda waktu belajar, disiplin terhadap diri sendiri untuk dapat menumbuhkan kemauan dan semangat belajar baik di sekolah seperti menaati tata tertib, maupun disiplin di rumah seperti teratur dalam belajar, disiplin dalam menjaga kondisi fisik agar selalu sehat dan fit dengan cara makan yang teratur dan bergizi serta berolahraga secara teratur (Hero, 2020). Disiplin merupakan cara masyarakat mengajarkan pada anak mengenai perilaku moral yang diterima oleh kelompok. Tujuannya adalah untuk memberitahukan kepada anak perilaku mana yang baik dan mana yang buruk serta mendorong untuk berperilaku agar sesuai dengan standar yang diperlukan. Hal yang diperlukan adalah peran para orang tua, orang dewasa ataupun guru untuk bisa memberikan stimulasi dan intervensi apa kepada anak agar anak mengetahui perilaku-perilaku yang diinginkan oleh standar kelompok sosialnya (Aulina, 2013). Pembentukan karakter Islami anak sangat penting, karena karakter Islami pada anak tidak akan mudah untuk diubah sampai anak tersebut dewasa nantinya, sehingga karakter inilah yang akan menjadi suatu penanda bahwa mereka adalah masyarakat muslim yang taat. Kearifan lokal yang dijalankan masyarakat muslim suku Sasak Desa Pejanggik berjalan semarak dan cenderung hybrid (Dozan \& Fitriani, 2020)

Dalam setiap kegiatan ekstrakurikuler pramuka mempunyai dampak tersendiri, baik itu dampak positif maupun dampak negatif. Berdasarkan dari beberapa data yang diperoleh, kegiatan ekstrakurikuler pramuka berdampak positif dalam membentuk karakter peserta didik di SDN I dan SDN 2 Talaga Raya dampak manajemen kegiatan ekstrakurikuler pramuka dalam membentuk karakter peserta didik di SDN I dan SDN 2 Talaga Rayaya itu berdampak positif. Dampak positif yang didapatkan peserta didik pada kegiatan ekstrakurikuler pramuka ialah dapat meningkatkan sikap disiplin peserta didik baik disiplin waktu, disiplin dalam berpakaian, dan disiplin mematuhi peraturan. Selain itu dapat meningkatkan sikap saling menghormati dan menghargai baik sesama teman maupun kepada pembina dan guruguru.

\section{SIMPULAN}

Perencanaan kegiatan ekstrakurikuler pramuka dalam membentuk karakter peserta didik di SDN I dan SDN 2 Talaga Rayaterbagi menjadi 2 (dua) perencanaan yang memuat pengetahuan dan keterampilan kepramukaan. Efek atau dampak manajemen kegiatan ekstrakurikuler pramuka dalam membentuk karakter peserta didik di SDN I dan SDN 2 Talaga Rayayaitu berdampak positif. Dampak positif yang didapatkan peserta didik pada kegiatan ekstrakurikuler pramuka ialah dapat meningkatkan sikap disiplin peserta didik baik disiplin waktu, disiplin dalam berpakaian, dan disiplin mematuhi peraturan. Selain itu dapat meningkatkan sikap saling menghormati dan menghargai baik sesama teman maupun kepada pembina dan guru-guru.

\section{UCAPAN TERIMA KASIH}

Terima kasih penulis ucapkan kepada kepala sekolah dan guru SDN 1 dan SDN 2 Talaga Raya dan semua pihak yang telah membantu pelaksanaan penelitian dan penulisan artikel ini. Tidak lupa ucapan terima kasih kepada editor dan reviewer Journal Obsesi yang sudah memberikan kesempatan sehingga jurnal bisa untuk diterbitkan. 


\section{DAFTAR PUSTAKA}

Agus Widodo, H. S. (2003). Ramuan Lengkap Bagi Pramuka Penggalang, Pramuka Penegak, dan Pembina Pramuka. In Yogyakarta: Kwartir Daerah XII DIY.

Aulina, C. N. (2013). Penanaman Disiplin Pada Anak Usia Dini. PEDAGOGIA: Jurnal Pendidikan, 2(1), 36. https://doi.org/10.21070/pedagogia.v2i1.45

Dozan, W., \& Fitriani, L. (2020). Membangun Karakter Anak Usia Dini Melalui Nilai-Nilai Islam Dalam Tradisi Perang Timbung. Murhum : Jurnal Pendidikan Anak Usia Dini, 1(1), 1-15. https://doi.org/10.37985/murhum.v1i1.2

Gartina, N., Garis, R., \& Refian Sunarti, N. (2019). Pelaksanaan Strategi Pemberdayaan Perempuan Oleh Pemerintah Desa Dalam Upaya Meningkatkan Kegiatan Usaha Kecil Menengah (Studi Di Kabupaten Pangandaran). Jurnal MODERAT, 5(3), 294-304. https://doi.org/10.25147/moderat.v5i3.2712

Hero, H. (2020). Implementasi Kegiatan Pramuka dalam Membentuk Karakter Disiplin Siswa Kelas V SD Inpres Boru Kecamatan Wulanggitang Kabupaten Flores Timur. Jurnal Ilmiah Wahana Pendidikan, 6(3), 295-307. https://doi.org/10.5281/zenodo.3737983

Hidayat, H., Yarshal, D., \& Suratno, S. (2019). Pendampingan Pendidikan Karakter Melalui Gugusdepan. Amaliah: Jurnal Pengabdian Kepada Masyarakat, 3(2), 390-395. https://doi.org/10.32696/ajpkm.v3i2.295

Ikawati Rahayuningtyas, D., \& Mustadi, A. (2013). Analisis Muatan Nilai Karakter Pada Buku Ajar Kurikulum 2013 Pegangan Guru Dan Siswa Sekolah Dasar. Pendidikan Karakter, 261-274. https:/ / doi.org/10.21831/jpk.v8i2.21848

Marzuki, \& Hapsari, L. (2015). Pembentukan Karakter Siswa Melalui Kegiatan Kepramukaan Di Man 1 Yogyakarta. Jurnal Pendidikan Karakter, 0(2), 142-156. https://doi.org/10.21831/jpk.v0i2.8619

Muhammad. (2015). Pembentukan Karakter Anak Sd/Mi Melalui Pendidikan Pramuka. Elementary: Jurnal Ilmiah Pendidikan Dasar, 1(2), 10-17.

Nasbi, I. (2017). Manajemen Kurikulum: Sebuah Kajian Teoritis. Idaarah: Jurnal Manajemen Pendidikan, 1(2), 318-330. https:/ / doi.org/10.24252/idaarah.v1i2.4274

Rambe, A. A. (2016). Pendekatan Sistem Dalam Perencanaan Dan Manajemen Pendidikan. Ta'dib, 14(2). https://doi.org/10.31958/jt.v14i2.208

Santoso, S., \& Hikmah, A. N. (2015). Upaya pembentukan Karakter Siswa Melalui Kegiatan Ekstrakurikuler Pramuka di Sdit Salsabila 2 Klaseman Sinduharjo Ngaglik Sleman. AlBidayah, 7(1), 0085-0034. https://doi.org/10.14421/al-bidayah.v7i1.155

Shaleh, M., \& Anhusadar, L. (2021). Kesiapan Lembaga PAUD dalam Pembelajaran Tatap Muka pada New Normal. Jurnal Obsesi : Jurnal Pendidikan Anak Usia Dini, 5(2), 21582167. https:// doi.org/10.31004/obsesi.v5i2.1139

Surono, K. A. (2018). Penanaman Karakter Dan Rasa Nasionalisme Pada Kegiatan Ektrakurikuler Pramuka Di Smp N 4 Singorojo Kabupaten Kendal. Indonesian Journal of Conservation, 6(1). https:// doi.org/10.15294/ijc.v6i1.12527

Usman, J. (2016). Urgensi Manajemen Pembiayaan Dalam Peningkatan Mutu Pendidikan Madrasah. TADRIS: Jurnal Pendidikan Islam, 11(2), 219. https:// doi.org/10.19105/tadris.v11i2.1170

Wahyuni, R., \& Erdiyanti. (2020). Meningkatkan Kemampuan Motorik Halus Anak Melalui Finger Painting Menggunakan Tepung Singkong. Murhum : Jurnal Pendidikan Anak Usia Dini, 1(1), 28-40. https:// doi.org/10.37985/murhum.v1i1.5

Wiyani, N. A. (2012). Pendidikan Karakter Berbasis Iman dan Taqwa. Teras. 